\title{
OS DIREITOS SOCIAIS ${ }^{1}$
}

\author{
SOCIAL RIGHTS
}

FABRIZIO POLITI ${ }^{2}$

\begin{abstract}
RESUMO: O presente artigo aborda a evolução dos direitos sociais no Estado social de direito, em especial na Itália, analisando a proteção constitucional destes direitos sociais, concluindo com os novos desafios dos direitos sociais no ordenamento europeu.
\end{abstract}

PALAVRAS-CHAVE: Direitos Sociais; Estado de Direito; Constituição.

ABSTRACT: This article discusses the evolution of social rights in the social state, especially in Italy, analyzing the constitutional protection of social rights, concluding with the new challenges of social rights in Europe legal system.

KEYWORDS: Social Rights; State of Law; Constitution.

PREMESSA: Questo articolo si illustra l'evoluzione dei diritti sociali nello stato sociale di diritto, soprattutto in Italia, analizzando la tutela costituzionale dei diritti sociali, concludendo con le nuove sfide dei diritti sociali nell'ordinamento Europeo. PAROLE CHIAVE: Diritti Sociali; Stato di Diritto; Costituzione.

SUMÁRIO: 1. A Oposição Tradicional em Matéria de Direitos Sociais e as Linhas de Desenvolvimento do Presente Trabalho; 2. Direitos Sociais e Estado de Direito; 3. As Primeiras Leis de Proteção Social; 4. Os Direitos Sociais na Constituição Italiana; 5. Os Direitos Sociais como Direitos Constitucionais Invioláveis; 6. Conclusões - A Função Social do Estado e as "novas fronteiras" dos Direitos Sociais entre o Ordenamento Regional e o Ordenamento Europeu; Referências Bibliográficas.

SUMMARY: 1. The Traditional Opposition in Social Rights and the Lines of Development of This Work; 2. Social Rights and Rule of Law State; 3. The First Laws of Social Protection; 4. Social Rights in the Italian Constitution; 5. Social Rights as Inviolable Constitutional Rights; 6. Conclusions - The Social Role of the State and the "new frontiers" of Social Rights between Regional and European Legal Order; References.

\footnotetext{
Artigo recebido em 04.06.2012. Artigo aceito para publicação em 13.08.2012 mediante convite.

${ }^{1}$ Publicado em R. NANIA, P. RIDOLA, I Diritti Costituzionali, vol III, Giappichelli, Torino 2006, 1019 e ss., Traduzido por Sandro Glasenapp Moraes, Mestrando em Direito pela Pontifícia Universidade Católica do Rio Grande do Sul.

${ }^{2}$ Professor de Direito Constitucional na Faculdade de Economia da Universidade de L'Aquila, Itália.
} 
SOMMARIO: 1. Le Tradizionali Contrapposizioni in tema di Diritti Sociali e le Linee di Sviluppo del Presente Lavoro; 2. Diritti Sociali e Stato di Diritto; 3. Le Prime Legislazioni di Protezione Sociale; 4. I Diritti Sociali nella Costituzione Italiana; 5. I Diritti Sociali quali Diritti Costituzionali Inviolabili; 6. Conclusioni - La Funzione Sociale dello Stato e i "nuovi confini" dei Diritti Sociali fra Ordinamento Regionale e Ordinamento Europeo; Nota Bibliografica.

\section{A OPOSIÇÃO TRADICIONAL EM MATÉRIA DE DIREITOS SOCIAIS E AS LINHAS DE DESENVOLVIMENTO DO PRESENTE TRABALHO}

A reflexão doutrinária em matéria de direitos sociais é sempre caracterizada de fortes e numerosas oposições conceituais (liberdade positiva versus liberdade negativa; justiciabilidade $v$. não justiciabilidade; Estado de direito $v$. Estado social; princípio da legalidade $v$. intervenção pública; liberdade $v$. igualdade; lei $v$. constituição; etc.), as quais, além de enfrentar o problema da definição (e mesmo a denominação) de "direito social", são elas próprias reflexos de outras dicotomias (reais ou presumidas) do direito constitucional, por exemplo, aquela entre discricionariedade e liberdade da atividade legislativa no confronto das normas constitucionais, entre norma programática e norma preceito, entre igualdade e liberdade e assim por diante.

E assim são registradas afirmações para sustentar uma peculiar "natureza" ou "estrutura" dos direitos sociais que os diferenciam dos direitos de liberdade e dos direitos políticos, considerando-os princípios meramente políticos, substancialmente diferentes dos direitos subjetivos e dos direitos de liberdade.

A mesma fórmula "direito social" foi considerada uma expressão agrupante de situações heterogêneas (previstas nas constituições longas e mistas da segunda metade do século $X X)$ e que compreende os próprios direitos como também situações "meramente recomendadas". Também Mortati (que não usa a expressão "direitos sociais, mas "direitos civis", definidos como "pretensão do particular contra o estado ou ente público a prestações em seu favor" e que "se distingue daqueles de liberdade porque pretendem obter do sujeito passivo o adimplemento de uma obrigação positiva de fazer") considera que as situações jurídicas abrangidas por tal denominação são distintas em razão da respectiva "instrumentalidade" com respeito aos direitos de liberdade. Os diversos direitos sociais diferenciar-se-iam internamente entre aqueles necessários a garantir o exercício pacífico ou assegurar a tutela dos direitos de liberdade (e cujo tratamento está ligado ao direito substancial correspondente) e aqueles direitos sociais que, ao invés, não estando ligados a direitos de liberdade, são "dirigidos a satisfação das diversas necessidades da pessoa"; estes últimos, por sua vez, devem ser distinguidos conforme o reconhecimento operado na carta constitucional.

Da mesma forma, foi observado (Mazziotti) que a mesma expressão "direitos sociais" é encontrada com frequência nos textos de direito positivo (art. 22 da Declaração de Direitos do Homem, "direitos econômicos, sociais e culturais", proclama os direitos ao trabalho, salário justo, a organização sindical, 
ao repouso, a limitação de horas de trabalho, às férias periódicas remuneradas, o direito ao seguro e assistência social, o direito das mães e de suas crianças a uma proteção especial, o direito à educação, à participação na vida cultural e os direitos do autor) e o Título II da Parte I da Constituição Italiana é intitulado "Relações ético-sociais". Por fim, pode-se citar a Carta dos direitos fundamentais da União Europeia, aprovada em Nice, no ano de 2000, e inserida no "Projeto de Tratado que institui uma Constituição para Europa", que contém um título (IV) intitulado "solidariedade" e que prevê diversas normas de proteção dos trabalhadores, de reconhecimento do direito de acesso às prestações do seguro social e aos serviços sociais, a prevenção sanitária e aos cuidados médicos, aos "serviços de interesse econômico geral", bem como as normas que asseguram um patamar elevado de proteção do ambiente e da proteção dos consumidores nas políticas da União.

As mencionadas reconstruções doutrinárias são indícios do destino que acompanhou a reflexão doutrinária e a evolução legislativa e constitucional dos direitos sociais. Com efeito, as tensões sociais e politicas no século XIX acompanharam e determinaram o nascimento das primeiras legislações de proteção social que acabaram por condicionar também a reflexão jurídica no século seguinte, em que aparecem facilmente os legados do século XIX, o que tem tornado difícil a adequada atenção ao pleno significado e as funções dos direitos sociais na forma do Estado constitucional.

De fato, nas democracias pluralistas do século $X X$ continua-se (pelo menos por parte de alguns) a opor os direitos fundamentais aos direitos sociais, ao invés de incluí-los todos na categoria dos "direitos constitucionais". Em vez disso, reconhecendo a uns e outros tais características é possível, por consequência, assegurar também aos direitos sociais aquela peculiaridade, a "multiplicidade de dimensões", própria dos direitos constitucionais das democracias pluralistas e que reflete a estrutura (também pluri dimensional) da sociedade aberta (RIDOLA). Em tal perspectiva, emerge a definição que parece correta seguir, segundo a qual o exame dos direitos sociais constitucionalmente reconhecidos não possa prescindir do papel e das funções que se pretende atribuir a Constituição.

E se a passagem do "estado de direito legislativo" para o "estado de direito constitucional" teve um efeito profundo também em relação a identificação dos princípios (ou dos valores) dos direitos fundamentais, que a respectiva legitimação numa perspectiva "externa" ao Estado (RIDOLA), é inevitável que na determinação do conteúdo das normas constitucionais encontre-se as tensões e conflitos que se registram na sociedade civil. Neste contexto, próprio da democracia pluralista, em que a função unificante da constituição se revela altamente problemática, a função dos direitos (enquanto expressão de um "sistema de valores") é aquela de ser um fator de permanente processo de integração. A questão a ser resolvida, portanto, é relativa a possibilidade, ou não, de abranger os direitos sociais entre os direitos fundamentais constitucionalmente reconhecidos e garantidos. Naturalmente, tal exame não 
pode prescindir do dado positivo apresentado, não só, da específica disposição constitucional, mas de toda a estrutura constitucional e da evolução histórica dos institutos jurídicos em análise.

Portanto, antes de qualquer análise mais aprofundada na matéria, é preferível expor a definição metodológica e a linha de desenvolvimento do presente trabalho. Este que escreve considera na verdade que no estudo da experiência jurídica (particularmente a respeito dos direitos sociais) os conceitos jurídicos, sendo diretamente determinados pela realidade social, não podem ser considerados como "único produto de uma lógica dedutiva sem nenhuma avaliação de valor em face de contexto histórico e social diverso". Naturalmente o direito é também instrumento de "composição oficial dos conflitos de interesse", mas consciente da sua historicidade, é sempre necessário tentar identificar quais são os "valores fundantes" dos diversos (propostos) conceitos constitucionais. A visão histórica dos conceitos (assim como dos institutos e dos princípios) jurídicos, e assim o exame das mutações dos contextos (social, econômico e cultural) vem assim a representar o principal instrumento de compreensão do significado dos mesmos (CERVATI).

O debate (antes do jurídico) cultural e político sobre o "Estado social" e sobre "direitos sociais" surge na Europa em estreita conexão com o progressivo crescimento da sociedade de massas, das ideologias político-econômicas contemporânea e da disciplina legislativa adotada, a partir da segunda metade do século XIX, mesmo em Estados não democráticos. Deve ser salientado que com a emergência da economia moderna todos os países se viram confrontados com enormes problemas sociais decorrentes seja da crise econômica cíclica, seja das condições do proletariado. Paralelamente (e com incontestável interferência recíproca) se registra uma ampliação da participação democrática que conduz a passagem do Estado liberal para o Estado Democrático pluralista.

E é nas constituições das democracias pluralistas que se torna constante a inserção dos direitos sociais (de fato presente, embora em formulações superficiais, também em algumas constituições liberais). E as previsões de direitos sociais nas Constituições escritas é trazida segundo duas linhas diferentes de desenvolvimento. De fato, estes são por um lado, postos como "missões" ou "programas" pelo legislador (e, portanto, as normas constitucionais relativas não estabelecem - ou não estabeleceriam - uma posição jurídica do particular imediatamente tutelável). Entre estas, pode-se citar a Constituição de Weinmar (ao menos pela forma como as disposições sobre direitos sociais foram interpretadas pela doutrina alemã da época) e também a Constituição de Bonn (que não contém - diversamente da nossa Constituição ${ }^{3}$ - um elenco dos direitos sociais, mas que estabelecem só o princípio do "Estado social de direito"). Na linha diversa de desenvolvimento se coloca aquelas constituições (como a nossa) em que, ao invés, os direitos sociais vêm colocados no catálogo dos direitos do citadão (e do indivíduo) e portanto a norma constitucional

\footnotetext{
${ }^{3}$ As referências a Constituição dizem respeito a Constituição Italiana. (NT)
} 
relativa estabelece um preceito imediatamente aplicável também se, por alguns aspectos, estes necessitam da atuação do poder público mediante uma implementação organizacional e instrumental, por vezes muito complexo. Como se buscará demonstrar melhor mais adiante, tal aspecto não pode ser considerado um enfraquecimento do âmbito do direito constitucionalmente garantido, enquanto que para tutela e gozo de todos os direitos é necessário (sempre!) a prestação, pelo estado de organização adequada dos instrumentos e pessoal (mais sobre o tema ver adiante).

Quanto ao nosso país, em primeiro lugar salienta-se o catálogo explícito dos direitos sociais na Constituição republicana que não fala mais de "estado social", e as disposições gerais (artigos $2^{\circ}$ e $3^{\circ}$ da Constituição), nas quais são encontrados os mesmos fundamentos primários. Esta consideração se revela central, pois indica a distância estelar entre os direitos sociais (invioláveis) reconhecidos pela Constituição e vários exemplos da legislação social aprovada em regimes não-democráticos, no sentido paternalista e/ou nacionalista. A Constituição, em seus quatro primeiros artigos já identifica claramente os princípios fundamentais de todo o sistema jurídico, o papel e a proteção da pessoa e dos direitos invioláveis da pessoa humana: a nossa é uma democracia pluralista que reconheceu o "direito inalienável" da pessoa (artigo $2^{\circ}$ da Constituição), "a igualdade social" de cada indivíduo, e onde o princípio da igualdade material tem o objetivo de pleno desenvolvimento da "personalidade humana" (e, para isso também inclui o direito "ao trabalho").

Antecipando as conclusões deste trabalho, se expressa desde logo a convicção de que os direitos sociais reconhecidos na Constituição - como qualquer outro direito constitucional - são simplesmente (mas com todas as consequências inevitáveis) "direitos constitucionais". O elemento peculiar dos direitos sociais e que fornece a esses o fundamento de valor é a relação de recíproca conexão que existe entre eles e o princípio democrático. É a afirmação progressiva deste princípio e sua base de valor (igualdade social de cada homem e de igualdade entre si) que leva a acreditar que é necessário (e até "justo") reconhecer o direito de cada indivíduo para desfrutar um mínimo de proteção (assistência, saúde, educação, etc.) que, se ausente, afeta a dignidade do sujeito e o impede de expressar plenamente sua personalidade e, portanto, mostra ser um obstáculo à concretização do princípio democrático. Por outro lado, a afirmação plena dos direitos sociais, permitindo ao indivíduo se libertar da miséria, dá sentido ao gozo dos direitos e liberdades reconhecidos e, portanto, prevê o desenvolvimento livre e pleno da personalidade e, portanto, um cidadão consciente e envolvido na vida democrática.

Os direitos sociais e a democracia pluralista, seguem portanto, unidos, tanto que tem-se argumentado que os direitos sociais, se não são essenciais para a democracia, são elementos de "qualificação" da mesma (Baldassarre). Mais adiante se analisará mais aprofundadamente a doutrina que acabamos de mencionar, mas, por hora, ela serve para realçar a forma como a reflexão sobre os direitos sociais deve ser desenvolvida em conexão com a temática 
dos direitos fundamentais, uma vez que os direitos sociais possuem a mesma natureza destes.

Consequentemente, a problemática relativa a determinação do conteúdo dos direitos sociais como direitos invioláveis é resolvida através de operações de ponderação e balanceamento entre os diferentes valores constitucionais. Seguindo esta abordagem serão examinadas (embora rapidamente e fazendo referência específica às contribuições constantes da presente obra dedicadas aos pontos específicos) as disposições específicas individuais da Constituição italiana.

Finalmente, vamos tentar delinear os "novos horizontes" dos direitos sociais, representados pela divisão de competências entre o Estado e as Regiões e do processo de desenvolvimento do ordenamento europeu, que afeta também a esfera de competência do Estado (quase até colocar em discussão a essência do papel deste ou seja, sua função social).

\section{DIREITOS SOCIAIS E ESTADO DE DIREITO}

Foi sustentado que a afirmação dos direitos sociais criaria uma tensão com o Estado de Direito e, mais precisamente, com os direitos de liberdade (FORSTHOFF). Sobre o tema, se revela necessário aprofundar preliminarmente a noção de "Estado de Direito", no entanto, é inegável que o Estado de Direito nasce (assim como qualquer outro instituto jurídico) como um fenômeno histórico e como uma evolução na forma de "Estado". O estado do século XIX não é um estado (plenamente) democrático, devido às restrições graves que ainda existiam no acesso ao direito de voto. A afirmação dos direitos sociais, historicamente determinada, se origina a partir das mudanças históricas e sociais e da afirmação gradual dos princípios de igualdade e liberdade, ambas no estado de direito e inicialmente não consideradas contraditórias

Em outras palavras, os direitos sociais, como posição subjetiva garantida à pessoa, responde às exigências que surgem como resultado da afirmação da sociedade de massas e classes sociais, que é a posterior "aterrissagem" dos princípios de liberdade defendidos nas constituições liberais. A polêmica que visa reduzir direitos sociais a fruto de uma visão marxista-socialista (ver, por exemplo, Carl Schmitt que os denomina "direitos socialistas") é negada pela história: as primeiras leis sociais são nascidos em estados longe do socialista e o eclipse do sistema comunista soviético mostrou que os direitos sociais contidos nas Constituições do mundo ocidental do segundo pós guerra nasceram e se desenvolveram de acordo com seu conteúdo específico. As resistências que ocorrem em relação aos direitos sociais provavelmente provêm da sua fixação aos anteriores esquemas conceituais e jurídicos e do temor comunista, ou mesmo de uma leitura errada dos direitos sociais, como significando a negação da liberdade e da propriedade.

A - suposta - oposição entre os direitos sociais e dos direitos de liberdade - e, portanto, entre o Estado de Direito e Estado social - parece quase reprojetar (em ordem cronológica inversa) a distinção entre Estado de 
direito e Estado policial, mas, obviamente, se esqueceu do fato que em nenhum país a afirmação dos direitos sociais levou ao enfraquecimento de qualquer (forma de) liberdade ou dos princípios do Estado de Direito. Além disso, o medo da interferência da autoridade pública na vida dos indivíduos (como uma limitação da liberdade destes) se revela infundado quando se reconstrói (e interpreta) os direitos sociais como consequência direta dos princípios (próprios do estado de direito) da igualdade, da liberdade e o princípio democrático: é na operação recíproca destes princípios reside a razão de ser e, portanto, o fundamento direitos sociais.

Com esta afirmação não se pretende argumentar que na transição do Estado liberal para o Estado pluralista, não há mudanças radicais: a igualdade liberal difere profundamente da igualdade substancial proclamada nas constituições pluralistas e democráticas do século $X X$, e portanto também a liberdade e o mesmo princípio democrático passam a ter conteúdos adicionais e novos. Ao mesmo tempo, não podemos deixar de recordar os elementos de continuidade e "desenvolvimento". E assim as constituições do pluralismo democrático propõe superar a oposição entre a esfera pública e a esfera privada da liberdade, porque não tutelam apenas a liberdade das pessoas frente ao poder público, mas garantem"a eficácia dos direitos de uma comunidade de indivíduos considerados na concretude das suas condições de vida".

O advento da democracia pluralista afeta as espécies de Estado de direito liberal do século XIX no sentido de que eles passam agora a ser espécies de Estado de direito democrático e pluralista. Sobre o princípio da legalidade, a mesma controvérsia em torno desse princípio vem a revelar-se como um problema extraviado, pois este respeita a atividade administrativa e porque a legalidade constitucional não pode ser resolvida em um mero paralelismo com a legalidade administrativa (e, o mesmo papel do tribunal constitucional, chamado a decidir sobre a omissão do legislador, não pode ser comparada à dos tribunais administrativos). Sobre o princípio da separação de poderes, o pluralismo democrático não pode vir a determinar o envolvimento na formação de grupos políticos, ainda mais, de acordo com as diferentes formas e modelos processuais, influenciar as decisões a serem feitas (Sociedade Aberta) levando a um reequilíbrio das posições das partes envolvidas.

A libertação dos indigentes da escravidão da necessidade permite a estes realmente desfrutar da liberdade (civis e políticas) formalmente reconhecidos como iguais para todos: os direitos sociais jogam o duplo papel de instrumento de implementação e que é possível melhorar ainda mais o princípio democrático enquanto permitem a participação efetiva de cada indivíduo na vida política e econômica do país, tutelando assim o substrato de valor da democracia representada pela igual dignidade de cada homem (Haberle).

O perfil da relação entre liberdade e igualdade (que é uma expressão da tensão entre a concepção "negativa" e a concepção "ativa" ou "positiva" dos direitos) também está sujeito (na transição entre o Estado de Direito no século XIX, e o pluralista do século seguinte) a uma mudança profunda. 
Além disso, se a igualdade significa não tanto um paradigma de distribuição igual, mas uma libertação das formas de subordinação social, a ligação entre liberdade e igualdade torna-se muito estreita e coloca em jogo o perfil de "responsabilidade" do indivíduo em relação aos outros.

Além disso, a dicotomia "estado de direito - estado social" é baseada na suposição de que o estado de direito excluiria a priori, em razão do princípio liberal, qualquer intervenção positiva do Estado. Essa configuração é típica da doutrina alemã (FORSTHOFF, que por sua vez descende de Carl SCHMITT e, antes disso, OTTO MAYER, R. VON MOHL, E F. VON STAHL) segundo a qual o Estado de direito "deve ser entendido principalmente como composto de elementos técnico-jurídicos aptos para definir a esfera de ação e intervenção do Estado e do âmbito da liberdade do cidadão".

Nesta perspectiva, o conflito entre e o estado de direito e o estado social baseia-se na dicotomia entre liberdade (estado de direitos) e participação (estado social) e é interessante lembrar que na reflexão científica ocorrida entre os séculos XIX e XX, se utilizou também a expressão (ao lado de "estado distribuidor", ou "redistribuidor", ou "estado de serviços") "estado regulador" (agora novamente em voga, em face do fenômeno da autoridade administrativa independente considerada um sintoma mais amplo de retração do Estado pela economia e pela função de prestação de bens e serviços). $\mathrm{Na}$ realidade, o Estado liberal demonstrou-se longe de ser indiferente quanto a organização das relações entre estado e sociedade e a vida social como um todo. $\mathrm{E}$ de fato tem sido amplamente demonstrado que o crescimento esperado dos (diversos) direitos sociais não surge como um fenômeno de ruptura, mas como um elemento de continuidade com a tradição liberal (AMIRANTE).

É fácil apontar que na criticada doutrina o Estado de Direito deve ser considerado como inteiramente desprovido de conteúdo, porém, desde a sua primeira aparição, o Estado de Direito também se caracteriza pela atenção às questões sociais: basta lembrar 0 art. 21 da Constituição de 24 de junho de 1793: "Os auxílios públicos são uma obrigação sagrada. A sociedade deve a subsistência aos cidadãos desafortunados, seja proporcionando-lhes trabalho, seja através do fornecimento dos meios de existência para aqueles que não estão em condição de poder trabalhar. "

Sem dúvida, a crítica realizada por Marx ao Estado de direito, como uma instituição para a consolidação e reforço do poder e da dominação da classe burguesa, também passou a fornecer material adicional para justificar aquela reconstrução doutrinária que, jogando com a oposição "estado de direito Estado social", nega a possibilidade de reconhecimento dos direitos (sociais) do indivíduo argumentando que as disposições constitucionais pertinentes impõe apenas "tarefas" para o legislador (tarefas a serem executadas em conformidade com os princípios da liberdade negativa).

Segundo esta abordagem existiria "uma resistência extraordinária do estado de direito em face das tentativas de preenchê-lo com conteúdo social" 
(FORSTHOFF), mas a experiência histórica demonstra a falácia dessa afirmação porque o Estado de direito foi preenchido com muitos conteúdos sociais paralelamente ao (complemento do) caminho de progressiva afirmação do princípio democrático. Além disso, este conceito parte do pressuposto de que a constituição e a administração constituiriam duas áreas reciprocamente impermeáveis, enquanto que os princípios constitucionais são a base que permeia todo o sistema legal em todos os níveis.

Os direitos sociais não são a negação do (todo ou parte dele) estado de direito, mas sim uma resposta elaborada dentro desse mesmo estado de direito a problemáticas específicas (política e social) do século XIX (e do XX) no que dizem respeito aos elementos formais do estado de direito e que constituem os elementos distintivos e caracterizantes do mesmo (princípio da legalidade, separação de poderes, o conceito de direito, a independência dos juízes, a garantia dos direitos fundamentais). Nenhum dos elementos essenciais do Estado de direito é negado pela afirmação dos direitos sociais, que tendem, ao invés de reforçar o papel da lei (em relação à fase organizacional, de específica atuação desta) bem como o papel do juiz (e, sobretudo - mas não só - em caso de omissão parcial ou total do legislador). As doutrinas de teor contrário (segundo as quais a afirmação dos direitos sociais, resultaria no abandono dos princípios) são baseadas, não surpreendentemente, em uma "absolutização" desses princípios que esquecem a origem e seu desenvolvimento histórico. E mesmo que se queira levar a discussão para um plano mais juridico-formal, pode-se replicar que os elementos formais do estado de direito continuam a funcionar plenamente nas constituições que (como a italiana) contém uma lista extensa de direitos sociais. Por conseguinte, é fácil concluir que nas constituições contemporâneas os direitos sociais são (simplesmente) direitos que protegem cada indivíduo que se encontre nas situações previstas de forma a garantir uma vida "digna" e a plena participação na vida (social e econômica, portanto) da política do país. É o progressivo crescimento do princípio democrático e, portanto, a necessidade de proteção integral do indivíduo, para preencher as formas do estado de direito de conteúdo substancial, vinculado em última instância ao valor da pessoa humana (proteção da dignidade do homem) e, portanto, o princípio fundamental da própria democracia.

Pelas razões acima expostas é de se rejeitar o argumento de que, ao passar de uma função como de mera definição dos direitos fundamentais "clássicos" (porque ele identifica as áreas em frente do qual a autoridade pública deve parar), distingue-os dos direitos sociais, que são considerados conceitualmente, estruturalmente e funcionalmente diferente dos primeiros. Os direitos sociais por outro lado, se concretizariam exclusivamente em prestações positivas (como "não buscam a liberdade, mas a participação") que o Estado oferece ao indivíduo (FORSTHOFF). Esta reconstrução da doutrina deve ser rejeitada, desde sua configuração inicial, pois entre os direitos clássicos fundamentais claramente detectáveis "direitos de participação" 
(basta pensar dos direitos políticos ou o direito ao juiz natural), e porque é incorreto abranger todas as posições jurídicas subjetivas protegidas no catálogo dos direitos sociais como "prestações positivas".

Com efeito, a oposição "direitos fundamentais - direitos sociais" (e seu conflito subjacente entre "liberdade e participação") é falaciosa. Mas, na realidade, essa se revela claramente instrumental em uma operação destinada a limitar a afirmação dos direitos sociais, mas que pode muito bem ser definidos como direitos individuais cujas esferas legais subjetivas foram reforçadas através da progressiva afirmação do princípio democrático e dos subjacentes princípios de dignidade e inviolabilidade da pessoa humana. Por outro lado, o argumento que sustenta insolúvel a oposição entre os clássicos direitos fundamentais (baseados na liberdade) e os direitos sociais (baseados em vez disso, no princípio da igualdade) que, requerendo a posição dos limites e restrições também no confronto de particulares estaria a limitar as liberdades fundamentais de terceiros indivíduos, termina por justificar uma reconstrução dos direitos sociais como meros princípios programáticos que necessitam uma implementação específica da legislação. É, portanto, a mesma abordagem de base, que vê a liberdade e a igualdade como princípios fundamentais antitéticos, tese que deve ser rejeitada, uma vez que a reconstrução dos direitos do indivíduo (e, mais genericamente, a relação do indivíduo com o Estado), segundo tal dicotomia se revela enganadora porque, em muitos casos, estes conceitos operam em função da complementaridade, e porque - em geral - o vasto catálogo de direitos fundamentais não podem ser reduzidos a unidades de acordo com esta abordagem.

Esta oposição é, na verdade, uma manifestação de falta de desenvolvimento de interpretações capazes de reinterpretar a expressão "Estado de Direito", tendo em conta as mudanças produzidas pelo surgimento de regimes de democracia pluralista. Todas as oposições demonstradas, portanto, eram destinadas a "enfraquecer" a extensão dos direitos sociais ou (mas o efeito é o mesmo) não conseguiram compreender a transformação de conteúdo que as fórmulas do século XIX (Estado de Direito, princípio da legalidade, etc.) sofreram com a extensão do sufrágio e, portanto, com o surgimento de uma democracia pluralista.

Subjacente a tensão entre a distinção de direitos de liberdade e direitos sociais vem também citada a distinção entre "liberdade positiva" e "liberdade negativa", compiladas por I. Berlin, mas (além do fato de que todos os direitos incluem um perfil positivo) deve ser acrescentado que esta operação é uma (errada) simplificação do pensamento de Berlin, segundo o qual que a liberdade "negativa" não é um bem em si, mas como parte do (mais amplo) conceito de liberdade positiva, simplificação, no entanto, facilmente explorável a fim de justificar a oposição (considerado por Forsthoff "tensão irreconciliável") entre o "Estado de direito liberal" e o "estado social". Em outro trabalho Berlin também explicou que "Liberdade e igualdade estão entre os principais objetivos perseguidos pelos seres humanos há séculos, mas a liberdade total 
para os lobos é a morte para os cordeiros; uma liberdade total dos poderosos, dos capazes, não é compatível com o direito que mesmo os mais fracos e menos capazes de ter uma vida decente. ...A igualdade pode exigir a restrição da liberdade daqueles que dominam. Sem um mínimo de liberdade são excluídas todas as escolhas e por isso não há possibilidade de permanecer humano ... mas pode ser necessário colocar limites à liberdade para dar espaço ao bem-estar social, alimentar os famintos, vestir os nus, dar abrigo aos desabrigados, para permitir que outros possam ser livres, para não obstruir a justiça e equidade". Também no pensamento de I. Berlin é, portanto, claramente aparente a crença que a proteção constitucional dos direitos sociais depende da realização do princípio da liberdade.

Além disso, a distinção entre direitos negativos (que seriam aqueles que protegem a liberdade mediante a exclusão do estado) e direitos positivos (que, pela promoção da igualdade, exigem mais do estado) e, portanto, entre a liberdade e os serviços públicos (e da distinção básica entre o Estado liberal e o Estado intervencionista), também conhecido como "liberdade para" e "liberdade de" foi justamente chamado de um "conto de fadas" que apesar de "sua relativa novidade ou sua manifesta inadequação" não pode perder seu condicionamento e capacidade de proporcionar "a base teórica para atacar e defender o estado de bem-estar "(Holmes - Sunstein), tanto que "presta-se para servir duas formas diametralmente opostas de ver": aquela dos conservadores que relaciona a liberdade individual e autonomia moral e os benefícios sociais a dependência insalubre e aquela dos progressistas que consideram os direitos de propriedade e a liberdade de contrato manifestações de egoísmo imoral e os direitos sociais expressão de solidariedade generosa. A fraqueza da base para essa dicotomia conduz inevitavelmente ao enfraquecimento de qualquer reconstrução científica, que quer construir sobre esta dicotomia.

A existência de um direito (de qualquer direito) não pode não compreender a capacidade de proteger desse mesmo direito em juízo. Isto é verdade tanto para os chamados direitos negativos para os chamados direitos positivos e todos os direitos "custam" porque todos pressupõem a existência de um sistema público, financiado por receitas fiscais, para o controle e proteção de tais direitos; e por isso "todos os direitos são direitos positivos", bem como toda a liberdade é sempre uma liberdade positiva. Para a proteção de qualquer direito (do direito de propriedade privada ao direito de postular em juízo) é sempre necessária a intervenção do Estado.

A oposição entre os direitos sociais e o estado liberal descende de duas premissas erradas: a primeira considera que a intervenção estatal sempre se materializa em uma limitação da liberdade do indivíduo; a segunda que o Estado liberal é caracterizado pela ausência de uma função social. Ambas as premissas estão erradas: a intervenção estatal é necessária também para proteger os indivíduos das invasões de suas respectivas esferas; o Estado liberal não é nada separado da sociedade civil, tanto que expressamente prevê que cada função deve ser realizada em conformidade com o princípio 
da legalidade e da aplicação do princípio fundamental da igualdade. Não por acaso, nas constituições registradas no ano da revolução francesa (bem como na legislação social elaborado pela Assembleia Constituinte de 1789) as declarações dos direitos sociais seguiram a proclamação do princípio da igualdade perante a lei. Também foi adequadamente colocado em relevo como a supressão da liberdade termina por determinar "enfraquecimento dos mesmos direitos sociais, que degradam ao nível de interesse mais ou menos eficazmente protegidos". Os direitos sociais, portanto, pressupõem os "clássicos" direitos de liberdade (tanto que a indefinição destes implica automaticamente o enfraquecimento dos primeiro) e se põe (não em oposição, mas) como uma "realização" das liberdades tradicionais, pois tornam efetiva a "libertação" do indivíduo, garantindo o respeito da dignidade de cada pessoa e o pleno gozo da liberdade proclamada. A oposição entre os direitos de liberdade e os direitos sociais é, portanto, errada, também porque ela acaba por perder as implicações recíprocas existentes entre essas categorias. "A garantia dos direitos de liberdade é a condição para que as prestações sociais possam ser objeto de direitos individuais, a garantia dos direitos sociais é uma condição indispensável para o bom funcionamento da democracia, portanto, para um pleno exercício das liberdades civis e políticas".

\section{AS PRIMEIRAS LEIS DE PROTEÇÃO SOCIAL}

Um rápido exame das primeiras normas de proteção social evidenciam primeiramente a diferença "qualitativa" aparente entre as primeiras normas nesta matéria e a posterior introdução na Constituição dos direitos relativos a elas e, em segundo lugar, mostra como a afirmação legislativa (entre a segundo metade do século XIX e primeiras décadas do século seguinte) dos primeiros "direitos sociais" é dependente da contemporânea ação de múltiplos fatores, muitas vezes autônomos e independentes, também foi uma resposta às necessidades comuns dos regimes diferentes. Embora a primeira legislação na Europa que introduziu o seguro obrigatório para todos os trabalhadores na indústria e para as pessoas com deficiência e idosos foi realizada pelo chanceler Bismarck na Alemanha (com duas leis de 1884 e 1889), deve ser apontado que as formas de assistência aos necessitados já eram presentes no ancien regime (lembre-se da chamada "lei dos pobres", adotada na Inglaterra em 1601 e que inspirou muitos outros países europeus, e com a finalidade de proporcionar formas de auxílio aos indigentes) e que o Título I da Constituição de 03 de setembro de 1791 previa a criação do instituto geral de "socorros públicos", voltados para "criar as crianças abandonadas, dar assistência aos pobres e doentes, e fornecer trabalho aos pobres, que não poderiam adquirir" e de uma "Educação Pública", "comum a todos os cidadãos, gratuitamente na parte de instrução indispensável necessária para todos os homens". Estes princípios foram reafirmados (embora com uma formulação diversa) nos artigos 21 e 22 da Constituição de 24 de Junho de 1793.

Nas primeiras décadas do século XIX, as teses liberais (em especial os ensinamentos de Ricardo e da escola de pensamento liberal que "nenhum 
plano para ajudar os pobres merece atenção a menos que eles tendam a colocar os pobres em condições de fazer ao menos o seu próprio socorro") foram invocadas na França para justificar a decisão de reduzir as formas de assistência aos pobres, mas a escolha veio, principalmente, pelo desejo das classes dominantes para manter uma baixa carga tributária. As exigências sociais facilitaram a difusão das ideias opostas do movimento socialista (no qual podemos englobar também as ideias dos socialistas utópicos como Fourier, Proudhon, Blanc, Blanqui) e do movimento social católico, do qual surge clara a expressão de art. $8^{\circ}$ da Constituição da Segunda República que "A República deve garantir a existência de assistência fraterna à existência dos cidadãos em estado de necessidade, seja proporcionando os recursos, seja com a concessão de ajuda para aqueles que são incapazes de trabalhar". O advento de Napoleão III levou à escolha do "paternalismo social" e só depois de mais de uma década pela emergência da Terceira República passou a ser adotadas normas de proteção social (a partir da Lei Ferry que previa a instituição da instrução primária gratuita e obrigatória até a idade de 13 anos, da Lei de 1898 que, seguindo o modelo alemão, introduzia o seguro voluntário de doenças e acidentes de trabalho, até que a lei de 1910 que introduziu a pensão obrigatória para todos os trabalhadores). Finalmente, o Preâmbulo da Constituição de 1946, expressamente referida no preâmbulo da Constituição em vigor, enumera uma série de princípios para proteger as crianças, os deficientes, os trabalhadores e o direito de todos a uma "existência digna".

Como dito, a primeira legislação social na Europa, foi adotada na Alemanha, onde, com uma reforma aprovada entre 1883 e 1889, foi introduzido como um seguro obrigatório por invalidez e velhice para os trabalhadores, financiado (em sua maior parte) por contribuições dos próprios trabalhadores e (o resto) pelos pagamentos dos empregadores e do Estado (que também arcava com os custos de gestão do regime). Esse seguro fornecia aos trabalhadores (garantia também o pagamento de metade do salário em caso de doença e livre de custos hospitalares) uma pensão de aposentadoria após 70 anos de idade e 30 anos de contribuições. Deve-se recordar que, por causa da esperança de vida da época (entre 55 e 60 anos), apenas 1\% dos trabalhadores chegava a idade da aposentadoria. Deve-se também destacar a absoluta novidade da reforma, embora com base em uma visão conservadora (a chamada Monarquia-providência, apoiado pelo lema: "a questão social que não pode ser resolvida pelo Estado"), em oposição não apenas às ideias socialistas, mas também às ideias liberais. E, de fato, Bismarck (que já tinha enviado a Paris em 1882 um Conselheiro de Estado para estudar na "Sociedade Científica universal de instituições de previdência" a organização previdenciária de outros países), a fim de garantir uma unidade de propósitos entre a classe trabalhadora e o Estado (no contexto de um Reich forte se não todo-poderoso - que impõe aos súditos suas próprias concessões), reintroduziu as corporações (e a propósito da função "conservadora" de leis de suporte das classes indigentes, é de notar que, desde 1842 estados alemães, 
através da lei que dispunha que as obrigações de assistência aos indigentes vinculados a comunidade - mas não de nascimento - pela residência, havia garantido uma útil circulação da força de trabalho em função do processo de industrialização na Alemanha). Deve-se, contudo, notar que a legislação social alemã do século XIX, juntamente com o crescimento da economia, favoreceu o alcance de um bom nível de bem-estar social e a introdução de uma maior capacidade de resposta face à crise econômica.

$\mathrm{Na}$ Inglaterra, onde o pensamento liberal não foi temperado nem pelo pensamento católico, nem pelo socialista, em 1834 foi revogada a lei sobre a pobreza com supressão dos auxílios estatais. Assim evoluíram as formas de assistência (Friendly Societies), criadas dentro do movimento operário, inicialmente surgiu entre os trabalhadores dos setores mais especializados e, posteriormente, alargado a todos os trabalhadores, e que (em troca do pagamento de contribuições), fornecia uma cobertura de seguro de doença e de desemprego. Em 1880, durante o governo conservador do Disraeli, foi implementada uma reforma que introduziu o ensino primário obrigatório a cargo do sistema público de ensino, a expansão do sistema de saúde (com a prestação de serviços médicos gratuitos para a camadas sociais mais pobres) e uma reestruturação das habitações dos trabalhadores. No período entre 1900 e 1914 os governos liberais de Henry Campbell e Henry Asquith introduziram, entre outros, o seguro obrigatório de doença e invalidez e pensões por velhice.

Mas é na Inglaterra, com base em ideias keynesianas, que se registra o momento (a apresentação do Plano Beveridge) que, sem dúvida, marca um ponto de virada sobre o papel do Estado para com os problemas sociais e, mais geralmente, a economia. De fato, se as legislações sociais do final do século XIX e início do século XX já representam importantes inovações, como a resposta do Estado para os problemas da industrialização, o Plano Beveridge ultrapassa mais estreitamente o âmbito relacionado com a proteção dos trabalhadores e pessoas pobres, colocando, ao invés, a responsabilidade do desenvolvimento global da sociedade a partir do desenvolvimento cultural, econômico e social. O "Plano Beveridge" (em homenagem ao idealizador do mesmo, o parlamentar liberal William Henry Beverdige, ex-reitor da London School of Economics e da Universidade de Oxford) foi um complexo plano apresentado em 1942 (e apoiado no slogan from the cradlle to the grave, do berço ao túmulo), que pretendia a assistência gratuita para todas as necessidades - desde a saúde à educação, do desemprego à aposentadoria que poderiam atingir o cidadão no curso de sua vida. O plano previa o seguro de saúde obrigatório e gratuito para todas as formas de previdência em caso de desemprego, viuvez, velhice e morte. Como dito, o Plano Beveridge, pela aplicação dos princípios desenvolvidos por Keynes, estava concentrado mais no papel do governo na economia e na vida da cidade: e assim também as formas de controle público dos salários e preços, a nacionalização dos setores mais importantes da economia (serviços postais, energia elétrica, 
transportes, gás e siderurgia, os correios), o fortalecimento da educação pública, e da nacionalização das construções. O Plano Beveridge foi aprovado em 1946 e entrou em vigor em 1948.

A legislação social alemã exerceu uma grande influência na Itália. E assim, quando, no final do século XIX, o país atravessava uma profunda crise social e econômica, tanto a doutrina quanto as instituições se voltaram para o exemplo da política social do chanceler Bismarck. Parece interessante lembrar, neste contexto que Umberto I, em seu discurso que abriu a XX legislatura (5 de abril de 1897) tinha a dizer: "Meu governo vai apresentar projeto de lei em favor dos trabalhadores, de modo que nos acidentes e na velhice eles tenham aquele conforto justamente desejado por muito tempo ... Esta medida inspira um sentimento de solidariedade, o amor ao próximo, que devem ser os principais fatores da nossa vida social e política." E em 1898 foi aprovada a lei de criação da Caixa nacional de previdência para invalidez e velhice dos trabalhadores (Lei $n^{\circ} 350$, de 17 de julho de 1898) e a Lei $\left(n^{\circ} 80\right.$, de 17 de março 1898) que introduzia o seguro obrigatório contra acidentes (mas que abrangia apenas determinados setores industriais, colocando como facultativa a adesão à caixa de previdência; é importante lembrar que depois de quatro anos da introdução da lei, apenas $7 \%$ da força de trabalho tinha uma cobertura de seguro por acidentes em comparação com $51 \%$ em relação ao mesmo período na Alemanha). Somente em 1919, pelo Decreto-Lei $n^{\circ} 603$ de 21 de abril de 1919 (e se recorreu ao decreto para superar a previsível resistência parlamentar) foi feito obrigatório o seguro de acidentes e velhice.

Nas duas décadas fascistas se registraram numerosas leis de proteção social que podem ser compreendidas (assim como elementos de busca de consenso) como um passo na progressiva estruturação do Estado totalitário: a proteção do trabalho das mulheres e crianças (r.d. no 653/1923), assistência hospitalar para os pobres (r.d. $\left.n^{\circ} 2841 / 1923\right)$, proteção à maternidade e infância (r.d. $n^{\circ} 2.277 / 1923$ ), assistência aos filhos ilegítimos e abandonados (r.d. $n^{\circ}$ 798/1927), instituição da ONMI (Obra Nacional pela Maternidade e Infância), a introdução do seguro-desemprego (r.d. $\left.n^{\circ} 3.158 / 1923\right)$, o seguro de invalidez e velhice (r.d. $\left.n^{\circ} 3.184 / 1923\right)$, o seguro obrigatório contra a tuberculose (r.d. $n^{\circ}$ 2.055/1927) e contra as doenças profissionais (r.d. n 928/1929), a Instituição do INPS e INAIL e da Caixa nacional de abono da família para a com a previsão de isenções fiscais para famílias numerosas (r.d. $n^{\circ} 1.312 / 1923$ ). Muitas dessas medidas, além de responder ao "modelo de família fascista" foram resolvidas em intervenções esporádicas, desprovido de valor orgânico e muitas vezes se revelaram modestos (se não nulos) quanto aos resultados.

Nos Estados Unidos da América a célebre crise financeira de 1929 (a crise financeira que provocou uma crise de superprodução no setor industrial e uma crise de liquidez no sistema bancário), foi enfrentada pelo governo da época com uma política não-intervencionista, que acabou por agravar a situação. Em 1932, com a eleição do presidente democrata Franklin Delano Roosevelt e o início do New Deal, foi iniciada uma política de apoio ao 
sistema econômico e social do Estado. Além da aprovação de várias leis para proteger o sistema produtivo e de crédito foi criado o instituto da Civil Work Administration, com o objetivo de empregar os desempregados em tarefas de interesse público, um moderno sistema de pensões foi aprovado e estabelecido por lei os direitos dos trabalhadores.

O exame superficial do nascimento da legislação social em diferentes países europeus e do grande intervalo de tempo com que foram introduzidas (em 1889 na Alemanha e em 1919 na Itália) mostra que, se o pressuposto das mesmas é representado pela questão social, na adoção das normas específicas, influíram múltiplos fatores: desde estudos de estatísticas sociais inspirados pelo positivismo às teorias emergentes sobre o Estado, do papel da organização sindical à composição dos parlamentos nacionais, do surgimento de partidos socialistas à influência da doutrina social católica (Gustapane). Mas a análise também destaca a diferença radical entre a lógica que inspirou as primeiras leis de proteção social e o reconhecimento social dos direitos previstos nas Constituições do segundo pós-guerra, em especial do catálogo, amplo e articulado, de nossa Constituição.

No entanto, parece justo acrescentar que os direitos implementados por essas leis também representaram uma primeira semente da qual brotou a consciência da relação íntima entre a qualidade de vida do indivíduo (que the proporciona a oportunidade de realmente desfrutar de qualquer liberdade ou direito constitucional garantido) e a participação plena e efetiva do mesmo na vida social e política do país.

\section{OS DIREITOS SOCIAIS NA CONSTITUIÇÃO ITALIANA}

O extenso catálogo de direitos sociais contidos na Constituição certamente caracteriza a Constituição italiana, que fornece proteção imediata constitucionalmente garantida às situações jurídicas subjetivas nele enumeradas. O "perfil individual" de tais direitos os fazem protegidos imediatamente e enfraquece a (superada) argumentação relativa à necessária interpositio legislatoris. As áreas especialmente protegidas pelas disposições constitucionais são aquelas relacionadas com emprego, saúde, educação e proteção da família.

Sobre o trabalho, art. $4^{\circ}$ da Constituição estabelece "o mais controverso dos direitos sociais", o direito ao trabalho, cujo conteúdo varia de interpretações doutrinárias entre o direito de ter um emprego (interpretação rejeitada pelo Tribunal Constitucional) e um conteúdo complexo (progressivamente definido pela jurisprudência) que por um lado, inclui o valor constitucional, vinculante para todas as autoridades públicas, de implementação de uma política econômica destinadas a maximizar o emprego e, por outro lado, inclui situações jurídicas subjetivas imediatamente protegidas como liberdade de escolha da atividade de trabalho, liberdade de acesso ao emprego (e, assim, por exemplo, a proibição de vínculos do tipo corporativo), o direito à tarefa, o direito de não ser arbitrariamente demitido, e assim por diante. A este respeito é importante lembrar que na jurisprudência constitucional é claramente encontrado um 
relacionamento próximo entre o art. $4^{\circ}$ da Constituição e os artigos $2^{\circ}$ e $3^{\circ}$ da Constituição que eventualmente podem ser um prenúncio de nova interpretação de resultados significativos (Baldassarre; mais a respetio $v$. Infra, $n^{\circ} 5$ ). Também, deve-se recordar a doutrina jus-trabalhista que define o direito ao trabalho (ex. Art. 4, inciso $1^{\circ}$, da Constituição) como "direito da pessoa de ter acesso a um posto de trabalho em uma posição equiparada à disponibilidade de trabalho" com a consequente obrigação do Estado de criar uma estrutura administrativa capaz de facilitar o encontro entre a demanda e a oferta de trabalho.

$\mathrm{O}$ art. 36 da Constituição estabelece diversas normas para a proteção do trabalhador: o direito à remuneração proporcional e suficiente para viver uma vida digna (primeiro parágrafo) o direito ao descanso (segundo e terceiro parágrafos) e de férias pagas (terceiro parágrafo). A jurisprudência reconhece esses direitos, como direitos subjetivos perfeitos, invioláveis, irrenunciáveis e inalienáveis, próprios da pessoa humana enquanto trabalhador. Estes também são os direitos reconhecidos às mulheres e às crianças no art. 37 da Constituição (igualdade de tratamento no emprego e na proteção das situações específicas), a liberdade sindical e o direito à greve (artigos 39 e 40 da Constituição). Permanece não efetivado 0 art. 46 da Constituição que prevê o direito dos trabalhadores a colaborar ("na forma e dentro dos limites estabelecidos por lei "), na gestão das empresas. A jurisprudência considera direitos subjetivos diretamente acionáveis e judicializáveis o direito à assistência e o direito à previdência (artigo 38, primeiro e segundo parágrafos da Constituição), o direito dos deficientes à educação e a formação profissional (art. 38, parágrafo terceiro da Constituição).

A Constituição (artigos 29, 30 e 31) estabelece especial atenção também à proteção dos direitos da família (aquela "sociedade natural fundada no casamento"): a igualdade moral e legal dos cônjuges, o direito dos pais de manter, educar e instruir os filhos (e o direito destes últimos serem mantidos, educados e instruídos), o direito de assistência moral e material. Quanto a instrução, os arts. 33 e 34 estabelecem a liberdade de ensino e de escolha da escola, o direito ao ensino obrigatório e, para os merecedores, o direito ao ensino superior. No que diz respeito à saúde o art. 32 da Constituição declara a proteção ao "fundamental direito do indivíduo" e os tribunais têm declarado que esse direito (imediatamente protegido) abranger não só o direito ao tratamento médico (que a Constituição prevê a gratuidade para os pobres), como também o direito a um ambiente saudável.

Estes direitos constitucionais são imediatamente acionáveis. Já foi apontado (Baldassare) que aos direitos sociais é atribuída a mesma sorte que os direitos de liberdade, enquanto originalmente concebidos como meros princípios políticos, gradualmente transformados em direitos reais juridicamente estruturados. Os direitos sociais são (hoje) direitos invioláveis e irretratáveis da pessoa, como afirmado repetidamente em termos claros, pela Corte Constitucional com relação ao direito à saúde (sentenças no 992 e 1011/1988), o direito à habitação (Sentenças $\left.n^{\text {os }} 404,217 / 1988,19 / 1994\right)$ o direito ao trabalho 
(Sentença $n^{\circ}$ 108/1994). A questão da necessidade de interpositio legislatoris não é subestimada quando o juiz não pode suprir uma inércia do legislador em relação à necessária organização de pessoal, bens e serviços (mas tal consideração vale também para o direito de agir em juízo e para a tutela do direito de propriedade), mas ao mesmo tempo não exclui a priori a possibilidade de decisão judicial que impõe atos e comportamentos à Administração Pública. Nesse sentido, a experiência da jurisprudência constitucional (bem como administrativa e ordinária) mostra a potencialidade ínsita na imediata prescritividade da norma constitucional. Ao mesmo tempo a jurisprudência constitucional tem destacado alguns aspectos problemáticos oriundos das decisões "normativas" relativas aos "custos" das decisões e a incidência das mesmas no sistema normativo. Mas tais considerações (para manter em mente, mas não superestimar) mostram um pouco a importância da intervenção (e, portanto, o papel) do legislador na aplicação de qualquer disposição constitucional. Demonstra-se assim a inutilidade da distinção entre normas preceitos e normas programáticas (para além do princípio enunciado pelo Tribunal Constitucional desde a sua primeira decisão $\mathrm{n}^{\circ} 1$ de 1956, rejeitando o critério de distinção das normas constitucionais e a prescritividade integral da Constituição), a interpositio legislatoris (id est, o fornecimento de ferramentas e serviços e de pessoal) se revela necessária para a execução de (quase) todos as normas constitucionais (basta pensar que a falta de um número adequado não só de juízes, mas também dos oficiais de justiça, necessárias para as notificações e, por exemplo. para a penhora, em um tribunal torna muito difícil, senão impossível, proteger próprios direitos).

Com relação ao conteúdo de cada um dos dispositivos constitucionais citados acima (referindo-se às contribuições específicas) observa-se que a determinação destes direitos é sempre o resultado de um balanceamento entre os diferentes valores constitucionais em jogo e da obra de interpretação "aberta" na qual participam todos os sujeitos do ordenamento.

Como foi apontado, recentemente, também por orientações da doutrina estadunidense (mais, veja já citado Mazziotti), o contraste entre os direitos de liberdade e dos direitos sociais, com base na necessidade - exigida apenas para os segundos - de uma organização adequada que proporcione o gozo efetivo, é falso porque a necessidade de prestação adequada do aparato organizacional do estado (ou, mais genericamente, do poder público), ocorre sempre garantir o efetivo gozo de qualquer (tipo de) direito. Os direitos e as liberdades do indivíduo dependem da força da ação pública e também a esfera privada "é defendida, na forma possível, graças à intervenção pública". Mas a consciência do "custo dos direitos" deve ser usado apenas para acabar a repetição (incorreta) das dicotomias ou a existência de presumidos limites ao operador do poder judiciário, da administração e da Corte Constitucional. A proteção e a garantia de um direito sempre envolve a intervenção estatal e, portanto, sempre envolve uma verba (e, portanto, uma alocação e distribuição) dos recursos. 
Mas o aspecto (embora importante) sobre os procedimentos e medidas de intervenção do legislador, como afirmado, não pode chegar a negar a operatividade do preceito constitucional. A este respeito, é útil lembrar que este resultado final, veio da doutrina weimariana (apesar de a divisão entre aqueles que sustentavam que as disposições constitucionais relativas aos direitos sociais eram Programmsätze - a saber, diretivas que aguardavam o legislador traduzir em preceitos normativos - e aqueles que sustentavam que o Staatszielbestimmungen oder Gesetzgebungsauftraege - isto é, regras que estabelecem que o legislador deve atuar e desempenhar um papel fundamental na interpretação das normas constitucionais), que terminava por considerar necessária a interpositio legislatoris como imprescindível passagem para tornar efetivo o gozo dos direitos sociais (portanto, considerado protegido apenas depois e dentro dos limites do quadro legislativo apropriado). Já foi relatado que a "oposição" entre os direitos imediatamente tuteláveis e os direitos que para o gozo se exige a intervenção do legislador tem servido para enfraquecer o alcance dos direitos sociais, como o argumento funcional de que as disposições constitucionais pertinentes contém apenas "indicação" ou "diretrizes "(Programmsaetze) para o legislador cuja necessária intervenção definirá o seu conteúdo (Anschutz, Thoma, Schmitt), ou "norma de princípio" que, embora vinculante ao legislador ordinário, estabelecem somente fins que o legislador é responsável por perseguir. Nesse ponto de vista foi claramente excluída a aplicabilidade direta dos direitos sociais reconhecidos na Constituição e, portanto, excluindo a sua proteção imediata. Assim, as declarações sobre os direitos sociais se revestiriam de um valor essencialmente políticoconstitucional e, portanto, uma posição inferior em termos de eficácia jurídica contra os direitos de liberdade.

O reconhecimento imediato da prescritividade das normas constitucionais, também com referência aos direitos sociais, estabelece uma ênfase especial sobre o papel inevitável da administração pública na dimensão democráticoparticipativa delineada, o já referido status activus processualis (Haberle), ou seja, a dimensão das garantias dos direitos através do processo abre novas possibilidades para a defesa dos direitos (Ridola).

\section{OS DIREITOS SOCIAIS COMO DIREITOS CONSTITUCIONAIS INVIOLÁVEIS}

Quanto ao significado dos direitos sociais na Constituição italiana, tem sido reconhecido, além da amplitude e da sistematicidade dos mesmos, que para eles a Carta Republicana atribui a garantia "própria dos direitos constitucionais (muitas vezes, de fato, dos direitos invioláveis)", assim diferenciando-se de outros ordenamentos nos quais os direitos sociais encontram fundamento somente na legislação ordinária. Da estrutura constitucional parece assim desenhado um "modelo" pluralista, articulado e complexo, depositário das instâncias das diversas Weltanschauungen presentes na Assembleia Constituinte e, portanto, rejeita qualquer forma de abordagem unilateral ou unidimensional. 
A leitura dos direitos sociais reconhecidos na Constituição, juntamente com os quatro primeiros artigos da própria Constituição, leva à conclusão (por razões que se tentará expor) que tais direitos são direitos constitucionais invioláveis. O princípio personalista contido no art. $2^{\circ}$ da Constituição (e que segundo Mortati tem notável afinidade com o princípio da inviolabilidade da dignidade humana afirmada no art. $1^{\circ}$ da Constituição alemã), estabelece o princípio da proteção da pessoa humana (e, portanto, da dignidade da pessoa), no contexto da democracia pluralista e, em seguida como valor de proteção do indivíduo enquanto imerso na concreta existência social. $\mathrm{E}$ a "igual dignidade social" dos indivíduos e, portanto, a relação entre o art. $2^{\circ}$ e o art. $3^{\circ}$ (tanto primeiro como o segundo parágrafos) da Constituição, confirmou no contexto do reconhecimento da dimensão "social" dos direitos, a rejeição pela Constituição de uma concepção meramente "negativa" dos direitos de liberdade, apresentando, ao invés, de apresentar o sistema de direitos constitucionais dotado de uma dimensão garantista e de uma dimensão programática e, nesta complexidade "os direitos constitucionais irão afetar os mecanismos de integração social, como máximas de estruturação.

Os direitos sociais, como uma expressão da democracia pluralista, tem sua base na proteção da dignidade humana: são, portanto, direitos constitucionais invioláveis, cobertos pelo raio de proteção do art. $2^{\circ}$ da Constituição. E, não surpreendentemente, na Assembleia Constituinte, por ocasião da aprovação do art. $2^{\circ}$ da Constituição, foi uma particular intervenção de Moro que fez convergir o compromisso entre católicos e a esquerda, definindo tal disposição um "critério seguro para uma luta, que ainda não acabou, e que não poderá acabar, a luta pela liberdade e por justiça social". Na intervenção de Moro (da qual emerge a conscientização da função dos direitos sociais para "libertação" do indivíduo) transparece a ligação entre a dignidade humana e direitos sociais, a fim de garantir e tornar efetiva uma democracia pluralista. E essa representa uma peculiaridade da Constituição italiana (e que a torna diferente da de outros países) de ter posto na base do ordenamento "a ideia de pessoa na sua simples dimensão de ser individual e ser social".

O princípio da dignidade humana representa o valor basilar (e não o objetivo a ser alcançado) do ordenamento democrático-pluralista e, portanto, dos direitos sociais. Mas a proteção dos direitos sociais, tornando cada indivíduo plenamente "partícipe" da vida econômica, política e social do País, por sua vez, leva ao pleno cumprimento do princípio democrático. E se os artigos $2^{\circ}$ e $3^{\circ}$ (tanto primeiro como o segundo parágrafos) da Constituição constituem o fundamento do Estado democrático-pluralista, os direitos sociais desempenham o papel de "componente essencial dos valores fundamentais da democracia" e constituem um componente crucial da "trama constitucional entrelaçadas de pluralismo político e social".

Segundo Baldassarre os direitos invioláveis podem ser divididos em "originários" (que representam condições logicamente necessárias para a 
democracia) e "derivados" (que constituem condições positivamente necessárias para a democracia). Em outras palavras, enquanto a ausência dos primeiros (também conhecidos como "gerais"), determina a impossibilidade da existência do próprio sistema democrático, o grau de execução dos segundos (também chamados de "especiais") constitui um critério de qualificação (e de significado) da democracia. Ao primeiro grupo pertencem os "direitos do homem e do cidadão", enquanto no segundo estão incluídos "outros direitos fundamentais que, apesar de afetar a própria existência da democracia, caracterizam, de modo determinante, o significado especial que a Constituição Ihe assinala". Pertencer a um ou outro grupo deriva das "diversas formas de "prejudicialidade" lógica de um certo direito em face do conceito de democracia pluralista."

Dos direitos sociais reconhecidos na Constituição alguns recaem no primeiro grupo, e outros no segundo; e isso explica porque, embora reconhecendo a natureza inviolável dos direitos constitucionais, alguns direitos podem permanecer por longos períodos não implementados: a democracia, embora afetada em termos qualitativos, não chega a sofrer um vulnus radical. Mas essa distinção (como previsto pela mesma doutrina que a propôs) não deveria ser "absolutizada", já que tais direitos podem ser considerados coessenciais para uma democracia pluralista, fundada sobre o valor da dignidade humana e que pretende, com o fim de garantir e tornar efetivo o princípio democrático, assegurar a todos os cidadãos (além da participação na vida econômica, política e social do país) a plena consciência da sua participação e seu papel em um ordenamento pluralista e democrático. E então, resta claro que esta distinção, que serve para "qualificar" os direitos constitucionais, não se baseia em uma diferença estrutural dos mesmos, mas apenas sobre a relação entre eles e o princípio democrático. Mas então, mesmo a partir dessa perspectiva, ressurge o cerne da questão: a realização efetiva do princípio democrático, numa democracia pluralista, não se esgota em uma mera forma, mas é preenchido de múltiplos conteúdos e da exigência de um respeito recíproco.

E de acordo com a configuração smendiana as instituições do Estado de Direito devem ser preenchidas com conteúdo substantivo, a fim de consolidar a importância do princípio democrático. De fato, para Smend, os direitos fundamentais "proclamam um determinado sistema de valores, um sistema cultural, destinado a ser o sentido da vida estatal constituída pela constituição". E uma diferente abordagem teórica (Rawls), reconhece que "a ignorância, a pobreza e a falta generalizada de recursos materiais podem impedir uma pessoa de exercer seus direitos e de usar tais oportunidades". Também não pode ser negligenciada a objeção de que a inclusão na Constituição de direitos que o país não é capaz de garantir, corre o risco de deslegitimar a própria Constituição, deve-se notar que a demanda por direitos surge fortemente da sociedade moderna em consequência de razões econômicas e políticas. $\mathrm{E}$ os argumentos que continuam a enfatizar a necessidade de interpositio legislatoris em relação aos direitos sociais, se revelam superados atualmente. 
E se é verdade que, do ponto de vista descritivo, "os direitos dependem, para os aspectos relevantes, do contexto", porque a forma como são interpretados e aplicados muda com alterações das circunstâncias e os avanços ou involuções do conhecimento, também é verdade que o estudioso não só não pode se contentar com uma visão descritiva, mas também devem tentar compreender as razões substanciais que conduzem a determinados resultados interpretativos que são os valores em jogo e cujos efeitos se produzem sobre a postura constitucional (CERVATTI). Assim, em relação aos direitos sociais, enquanto espécies de direitos constitucionais tutelados como todos os outros direitos escritos na Constituição, a pergunta a se fazer não é tanto "protegidos ou não protegidos?", mas sim "protegidos até que ponto?". Esta questão reabre o debate em torno das garantias constitucionais dos direitos e da determinação do conteúdo essencial do mesmo (ver Ridola). A abordagem preferida, neste sentido, é aquela de orientada para determinar o conteúdo do direito constitucional através de um balanceamento entre os valores constitucionais em jogo. De acordo com o ensinamento haeberliano o balanceamento é uma operação dinâmica e interativa que, com base na função unificadora da Constituição em democracias pluralistas, se conecta diretamente ao paradigma smendiano da constituição como um processo dinâmico de integração do pluralismo social. E a ideia da Constituição como norma e missão parece adaptar-se bem ao conceito proposto dos direitos sociais, tornados imediatamente prescritivos e originadores de direitos individuais (e assim "norma"), mas também com a função de assegurar o cumprimento do princípio democrático mediante a garantia da tutela da dignidade humana (e, portanto, uma "missão"). Na base desta reconstrução é claramente visível uma teoria multidimensional dos direitos fundamentais, atenta para 0 significado dos processos participativos.

Como dito, na base de tal construção se encontra no princípio basilar da dignidade humana (Menschenwürde) não como um indivíduo preso em sua esfera individual, mas como um indivíduo em relação com outros indivíduos e, portanto, com atenção para o aspecto da responsabilidade do individuo. Como bem sustentado (Ridola) Haberle "vê na dimensão comunicativa da esfera pública o lugar no qual se compara processualmente as ambivalências e se abre à inovação virtual das constituições de democracia pluralista". De fato, segundo Haberle "no Estado social de direito, a reivindicação de liberdade individual e a proteção da comunidade são instâncias igualmente legítimas. Como as garantias de liberdade não decorrem do princípio do Estado social como regra e exceção, mas como tese e antítese, que, em última análise chegam a uma síntese e a um equilíbrio, os limites postos aos direitos fundamentais em face da garantia do estado social não pode ser degradado em exceções.... A liberdade individual e o vínculo social se encontram, portanto, no equilíbrio entre eles".

$\mathrm{E}$, além disso, há muito tempo a doutrina tem negado que os direitos sociais são direitos de "grupo" ou que tenham por finalidade (imediata e imperiosa) 
interesse coletivo e que só por via reflexa protegeriam interesses individuais. Os direitos sociais tem "caráter individualista" de modo que "a antítese entre direitos individuais e sociais não existe" (Mazziotti).

Os direitos sociais (que encontram seu fundamento seja no princípio da igualdade, seja no art. $2^{\circ}$ da Constituição) não se colocam em antítese com os direitos de liberdade uma vez que "a garantia dos direitos de liberdade é a condição para que as prestações estatais possam ser objeto de direitos individuais" e "a garantia dos direitos sociais é uma condição para o funcionamento adequado da democracia, portanto, para um pleno exercício das liberdades civis e políticas". E assim, confirma-se a validade da reconstrução de Baldassarre, segundo o qual os direitos sociais "qualificam" a democracia ( $v$. supra). E que a tutela da liberdade do indivíduo termina por envolver sempre uma atenção também aos direitos sociais é confirmada pela especial atenção dada à proteção social nas Constituições da França revolucionária e na legislação social elaborado pela Constituinte de 1789.

Para concluir, pode-se remeter as magistrais considerações de Mazziotti que, ao rejeitar o argumento de que os direitos sociais não estão sujeitos à proteção constitucional, afirma explicitamente que a Constituição protege os direitos sociais "na medida em que tutela todos os outros direitos que garante", contestando o argumento de que os direitos sociais teriam um caráter relativo e condicional (e por tal caráter estariam em conflito com os direitos de liberdade). E, já há quarenta anos, concluía: "É claro que os direitos sociais dependem, na sua realidade concreta, da organização do Estado, mas é pura ilusão pensar que o mesmo não é verdadeiro para os direitos de liberdade."

\section{CONCLUSÕES - A FUNÇÃO SOCIAL DO ESTADO E AS "NOVAS FRONTEIRAS" DOS DIREITOS SOCIAIS ENTRE O ORDENAMENTO REGIONAL E O ORDENAMENTO EUROPEU}

O conceito de direitos sociais é diretamente descendente da função social que se pretende atribuir ao Estado contemporâneo. E em um sistema econômico e econômico-financeiro que acelera de maneira desproporcional as possibilidades de ganhos e de lucro pelos detentores de capital, inevitavelmente condenado a uma posição de subordinação permanente aqueles que se encontram em condição de pobreza, o papel do setor público (sob pena de perder o seu sentido de valor) é exatamente aquele de uma função de "equalização" e "redistribuição" (a esse respeito deve-se notar que, neste sentido, também se expressa na doutrina social da Igreja Católica na encíclica Centesimus Annus, João Paulo II reafirmou a permanência da validade do conteúdo da ecíclica Rerum Novarum de Leão XIII, tem reiterado que o Estado, em todas as suas funções, deve ser o garantidor dos direitos individuais e sociais que permitem que os seres humanos se expressem em toda a sua complexidade). Esta definição não significa que os direitos sociais têm um propósito de caridade em vez de justificação dos direitos sociais, além 
de perfis personalista acima referido, deve-se acrescentar também a definição utilitaristra-contratualista, segundo a qual "todos os direitos dependem da disponibilidade da comunidade para contribuir "(Holmes-Sunstein).

De fato, nas constituições ocidentais o reconhecimento dos direitos (e não apenas aqueles social) tem como objetivo fornecer ao particular um conteúdo concreto à sua respectiva liberdade, de modo a permitir uma igualdade substancial entre todos os cidadãos (na conscientização que somente mediante tal circuito é possível a efetiva realização princípio democrático, qual seja, a participação efetiva em toda a vida social e democrática do país), mas não se pode negar a existência de um perfil adicional de justificação que considera os direitos (incluindo social) como expressão do contrato social. $\mathrm{E}$ de acordo com este paradigma, mesmo se alguém argumentar que a primeira tarefa do Estado seria a de proteger a propriedade privada (e com os instrumentos de uso mínimo possível de coerção) não seria difícil identificar a justificação dos direitos sociais na exigência da defesa da propriedade privada, graças a pergunta: como se pode "legitimar a riqueza aos olhos dos pobres"? Essa legitimidade só pode ser desencadeada pelo reconhecimento a uma educação livre, a existência de chances viáveis de ingresso no mercado de trabalho e a ampla disseminação da propriedade privada e das formas de distribuição dos recursos coletivos (Holmes-Sunstein). De acordo com esta abordagem tanto os direitos sociais, quanto a (tutela da) propriedade privada são expressões do pacto social o qual acaba por minar a validade de se permitir que os membros mais fracos da sociedade devem viver abaixo do nível de subsistência.

Não é possível aqui traçar a evolução do pensamento jusnaturalista do contratualista, mas pode parecer interessante notar que a opinião doutrinária por último mencionada vem (embora mediante um percurso diferente) identificar (também) critérios para a justificação das limitações que a afirmação de alguns direitos sociais em detrimento de outros direitos (como direitos de propriedade ou da liberdade de iniciativa econômica).

Portanto, se no passado os direitos sociais foram analisados em antítese com os direitos de liberdade, atualmente é necessário desvincular dessa dicotomia e para esse fim pode ser mais útil distinguir os problemas originários da dificuldade objetiva de garantia concreta dos direitos sociais (a cobertura financeira) dos problemas relacionados à natureza jurídica do mesmo. Mas - é bom repetir - este aspecto não diferencia de todo os direitos sociais dos outros direitos constitucionais porquanto para o gozo de cada um deles não se pode prescindir da realidade concreta da organização do Estado. Qualquer direito existe na medida em que o Estado estabelece e torna operacional uma adequada organização do poder público: a intervenção positiva do Estado (e mais geralmente da administração pública) é necessária para tornar efetivo o exercício e gozo de todos os direitos.

Essas considerações podem definitivamente rejeitar essas definições que, aproveitando também a distinção entre as normas programáticas e os preceitos, 
tendem a ligar os (problemas de funcionamento do aparato que deve assegurar gozo de) direitos sociais com a estrutura legal dos mesmos (precisamente a fim de demonstrar que o gozo imediato não dependem da natureza jurídica dos mesmos). Como observado da dicotomia conhecida de "normas programáticas - preceitos", fez justiça o Tribunal Constitucional desde a sua primeira decisão (Acórdão $n^{\circ} 1 / 1956$ ) e a doutrina mais atenta demonstrou claramente a "impropriedade lógica" (Baldassare) inerente a operação que tende a vincular os problemas de implementação dos direitos sociais com a sua natureza jurídica.

Além disso, a análise rápida (anteriormente desenvolvida) da origem das primeiras legislações sociais demonstra que, em diversos países, elas tiveram causas e origens muito diferentes uns dos outros. De fato, se na Inglaterra e na França foram governos de maioria socialista ou trabalhista levar adiante as leis de proteção social, o seguro obrigatório para todos os trabalhadores na indústria e para as pessoas com deficiência e idosos foi feita pelo chanceler Bismarck na Alemanha, com duas leis de 1884 e de 1889, enquanto na Itália na época pré-republicana as principais leis de proteção social foram introduzidas sob governos conservadores (na época estatutária) e mais ainda durante o regime fascista. Então, quem leva a marca enfatiza a progressiva afirmação legislativa dos direitos sociais, na verdade depende da "resposta de modernização" que vieram dos antigos estados liberais para os fenômenos da industrialização e democratização do processo decisório (Baldassare, Cervati), e a partir dessa perspectiva é confirmada a "função social" do estado). E mesmo Kelsen reconhece aos direitos sociais o papel de componente decisivo do processo de democratização (na verdade, em nítido contraste com Schmitt que, em vez disso, reconstrói os direitos sociais - como definido pelo mesmo "socialista" - como resultado do comprometimento da tensão dialética entre o liberalismo e o socialismo).

Portanto, pode ser considerado ultrapassada a oposição entre liberdade e igualdade que, desde seu aparecimento acompanhou a reflexão doutrinária em termos de direitos sociais, oposição que os direitos sociais fundiriam com a compressão da liberdade e o benefício da igualdade. Os direitos sociais estão buscando a afirmação da igualdade substancial, com vista a tornar efetivo para cada indivíduo o gozo das proclamadas liberdades sob o pressuposto da necessidade de proteger a dignidade do homem que, libertado apenas por necessidades primárias, pode (desfrutar da liberdade e portanto) participar da vida social e política (com a plena afirmação, portanto, também do princípio democrático, que é enriquecido porque quanto mais cada cidadão participar plenamente na sociedade, mais o princípio democrático poderá ser considerado satisfeito e realizado).

Finalmente, passando da (elaboração da) noção de "constituição econômica" e através do estudo das disposições constitucionais relativas aos bens econômicos, foram registradas teses que, ressaltando o caráter "privado" da economia, afirmaram a exigência de uma menor intervenção 
estatal na economia (e, portanto, em geral, na vida social). A Weltanschauung subjacente a esta abordagem é bastante evidente, mas também desfrutou dos efeitos do desenvolvimento dos ordenamentos europeus baseados em uma retratação pública do poder econômico (por causa da garantia da liberdade de concorrência), e (depois de Maastricht) na explícita afirmação do princípio da subsidiariedade (projetada, assim, em nosso ordenamento jurídico nas duas versões da subsidiariedade em sentido "vertical" e "horizontal").

Estas últimas considerações também delineiam as "novas fronteiras" dos direitos sociais (neste estudo somente mencionadas), representada pela distribuição de funções entre o Estado e as Regiões e as autoridades locais. Faz-se, naturalmente, referência ao art. 117 , parágrafo $2^{\circ}$, letram $m$ ) da Constituição (que reserva a competência legislativa exclusiva do Estado a "determinação de níveis essenciais de benefícios relativos aos direitos civis e sociais a ser garantido em todo o território nacional), mas também para o seguinte parágrafo $3^{\circ}$ (que coloca entre as matérias de competência legislativa repartida a proteção e segurança no trabalho, educação, saúde, previdência complementar e integrativa) e o parágrafo $4^{\circ}$ (critério residual em favor das Regiões) e o art. 118, primeiro parágrafo da Constituição (relativo à divisão de funções administrativas) e quarto (o princípio da subsidiariedade em sentido horizontal).

Parece enfim importante recordar que já a Lei de 18 de novembro de 2000, $\mathrm{n}^{\circ}$ 328, "Lei geral para a implementação do sistema integrado de intervenções e serviços sociais" (embora aprovada antes da reforma constitucional do ordenamento regional) segue a mesma lógica da divisão de funções entre as autoridades locais e entre os sectores público e privado contido no art. 118 da Constituição.

Também vale a pena mencionar a influência exercida do ordenamento europeu: da "infiltração" do direito comunitário em concorrência com os sistemas nacionais de droit social (Giubboni) a mais específica política social europeia (das Cartas Sociais de 1961 e 1989, a nova Carta Social Europeia em 1996, a Carta de Nice ao "Tratado que institui uma Constituição para a Europa"). Embora rapidamente, se evidencia que a prevalência assinalada anteriormente à constituição econômica (e, portanto, ao mercado) está começando (pelo menos em algumas reflexões preliminares) a dar lugar ao reconhecimento da existência de um núcleo de valores e direitos sociais, mesmo se as linhas de fundo da agenda social europeia surja com indicações contraditórias quanto ao conteúdo contemporâneo dos objetivos políticos neo-liberais e estratégias neo-corporativistas.

O perfil comunitário evidencia de modo particular o aspecto dos direitos sociais associados com a intervenção pública em geral e, particularmente, na economia. Neste sentido emerge com maior clareza a consciência da necessidade de regulação (ou regulamentação) do mercado - auto ou hétero dirigidos - seja pela exigência do correto funcionamento dos mesmos, seja 
para não negligenciar exigência relativa a afirmação da liberdade plena e efetiva do indivíduo e o reconhecimento pleno da dignidade humana e, portanto, do princípio democrático.

$\mathrm{E}$, frente aos problemas do custo dos direitos sociais, mesmo na fase atual de crise econômica pode ser útil recordar que já em 1926 em face do aumento dos custos (de então!) Estado social, frente ao dogma liberal do laissez faire, que terminou por impor cortes de gastos para o estado social, John Maynard Keynes sustentou (e demonstrou) que as crises cíclicas econômicas não seria enfrentada com um corte nos gastos sociais, mas sim com uma intervenção decisiva na economia e ações públicas destinadas a incentivar um aumento na demanda por bens de consumo e uma redistribuição mais equitativa dos recursos. As soluções a serem adotadas devem ser procuradas não no simplista "cortes de gastos", mas no desenvolvimento de novos modelos de welfare que levem em conta as novas fronteiras de conquistas científicas, que (por exemplo) em matéria de saúde, influenciam sobre a prevenção, e também, sempre que possível, no envolvimento dos vários níveis territoriais de governo e dos particulares porque esta não representa uma mera operação de retirada de parte do poder público. A história ensina que os problemas sociais, se não tratados adequadamente, sempre acabam ganhando os holofotes da agenda política (e não por coincidência as leis, e antes mesmo os debates, relativos aos "direitos sociais" foram registradas próximas de duas imponentes crises econômicas como a de 1873 e a de 1929).

Portanto, também a tese, de algumas décadas atrás, que propunham formas de redução da assistência pública demonstram ignorar a forte estabilidade agora alcançada pelos direitos sociais e seu significado em modernas democracias pluralistas.

Os direitos sociais, de fato, não só não torna os indivíduos irresponsáveis (a história e a análise comparada demonstram que os países onde os direitos não são reconhecidos são caracterizados por uma maior irresponsabilidade tanto individual quanto coletiva) mas, mais ainda, pressupondo que o Estado intervenha para direcionar os comportamentos individuais para um fim social, abre a estes uma "cultura dos direitos", que é também uma "cultura da responsabilidade e, portanto, do dever".

Os direitos vem assim a ter a função de instrumentos de uma estratégia de inclusão num quadro pluralista constitucional de uma sociedade aberta e comunicativa. Os direitos sociais, portanto, compartilham a mesma natureza e têm a mesma finalidade (e custam tanto quanto) os direitos de liberdade original.

E a organização, necessária para garantir o pleno exercício dos direitos, no entanto, merece atenção enquanto inevitavelmente ligada à eficácia dos mesmos. E o crescimento em tamanho e complexidade de órgãos públicos revela outros aspectos ligados ao risco de discriminação e de ocorrência de 
situações de inadequada proteção. Neste sentido, tem sido lembrado, como foi colocado em evidência, o potencial inerente a garantia dos direitos através do procedimento do status activus processualis que sintetiza a posição do titular dos direitos, no estado prestacional (e estas considerações ressaltam a importância de uma administração democrática e participativa).

Em conclusão pode, portanto, ser considerado ultrapassado (além da expressão "estado social") a mesma expressão "direitos sociais" enquanto resultado (e ligado a época) da oposição e sobretudo porque, no estado democrático pluralista, pode ser encontrado um catálogo de direitos de base constitucional e que representam o núcleo inviolável do indivíduo e que merecem, por tal razão, proteção e segurança, assegurando a efetiva liberdade do indivíduo, garantindo também a plena realização da essência do princípio democrático.

\section{REFERÊNCIAS BIBLIOGRÁFICAS}

AMATO, G. Il Mercato nella Costituzione, Quad. cost., 1992.

AMIRANTE, C. Presentazione, in FORSTHOFF, E. Stato di Diritto in Trasformazione; Giuffrè, Milano, 1973.

ANSCHÜTZ, G. Die Verfassung des Deutschen Reichs, Berlin, 1933, 584.

BALDASSARRE, A. Diritti Sociali, in Enc. Giur. Treccani, vol. XI, Roma, 1989.

BALDASSARRE, A. Diritti della Persona e Valori Costituzionali, Giappichelli, Torino, 1997.

BALDASSARRE, A., CERVATT A. A. Critica dello Stato Sociale, Aterza, Bari, 1982.

BERLIN, I., Four Essays on Liberty, New York, 1969, Traduz. it, Quattro saggi sulla Libertà; Feltrinelli, Milano, 1989.

BERLIN, I, La Ricerca Dell'ideale (1959), in Id., Il Legno Storto Dell'umanità. Capitoli della Storia delle Idee, a cura di HARDY, H. Adelphi, Milano, 1994.

BOBBIO, N. Eguaglianza ed Egualitarismo, in Riv. Int. Fil. Dir., 1976.

BUCHANAN, J. M. Stato, Mercato e Libertà, II Mulino, Bologna, 1989.

CALAMANDREI, P. L'avvenire dei Diritti di Libertà, in Opere Giuridiche, III, Napoli, 1968, 200.

CERRI, A. Eguaglianza Giuridica ed Egualitarismo, Japadre, L'Aquila, 1982.

CERVATT A. A. A Proposito dello Studio del Diritto Costituzionale in una Prospettiva Storica e della Comparazione tra Ordinamenti Giuridici, in Diritto Romano Attuale. Storia, Metodo, Cultura nella Scienza Giuridica, n 211999, Le Costituzioni e la Storia, 15 ss.

D'ANTONA, M. II Diritto al Lavoro nella Constituzione e nell'ordinamento Comunitario, in Riv. Gius. Lav., 1999, suppl. no 3.

ESPOSITO, C. La Costituzione Italiana. Saggi, Cedam, Padova, 1954.

FABBRINI, S. Politica e Mutamenti Sociali. Alternative a Confronto sullo Stato Sociale, II Mulino, Bologna, 1988.

FLORA, P.; HEIDENHEIMER, A. J. (a cura di), Lo Sviluppo del welfare State in Europa e in America, II Mulino, Bologna, 1983.

FORSTHOFF, E. Stato di Diritto in Trasformazione; Giuffrè, Milano, 1973. 
GIANNINI, M. S. II Pubblico Potere. Stati e Amministrazioni Pubbliche, II Mulino, Bologna, 1986.

GIUBBONI, S. Diritti Sociali e Mercato. La Dimensione Sociale Dell'integrazione Europea, Bologna, II Mulino, 2003.

GURVITCH, E. La Dichiarazione dei Diritti Sociali, Ed. di Comunità, Milano, 1949.

HABERLE, P. Stato Costituzionale, in Enc. giur. Treccani, vol. XXIX, Roma, 2001.

HABERLE, P. Le Libertà Fondamentali nello Stato Costituzionale, traduz. it., Nis, Roma, 1993.

HABERMAS, J. La Costellazione Postnazionale. Mercato Globale, Nazioni e Democrazia in una Prospettiva Europea, traduz it., Milano, 1999.

HOLMES, S.; SUSTEIN CASS, R. The Cost of Rights. Why Liberty Depends on Taxes, New York, W. W. Norton, 1999, traduz. it., Il Costo dei Diritti. Perché la libertà dipende dalle tasse, II Mulino, Bologna, 2000.

LAVAGNA, C. Istituzioni di Diritto Pubblico, Utet Torino, 1985.

LEIBHOLZ, G. Der Strukturwandel der modernen Demokratie (1952), in Strukturprobleme der modernen Demokratie, Karlsruhe, 1967.

LUCIANI, M. Sui Diritti Sociali, in Dem. dir., 1995.

MAESTRO BUELGA, G. Constitucion Economica y Derechos Sociales en la Union Europea, in Riv. dir. com. eur., 2000.

MAZZIOTTI, M. Diritti Sociali, in Enc. Dir., XII, Milano, Giuffrè, 1964.

MENGONI, L. I Diritti Sociali, in Arg. dir. lav., 1998, nº 1.

MENY, Y.; THOENIG, J.C. Le Politiche Pubbliche, II Mulino, Bologna, 1991.

MORTATI, C. Istituzioni di Diritto Pubblico, II, Cedam, Padova, 1976.

NIPPERDEY, H. C. (hg.). Die Grundrechte und Grundpflichten der Reichsverefassung, I, Berlin, 1930.

ORAGHI, L. (a cura di). La Nuova età delle Costituzioni, II MUlino Bologna, 2000.

PRINCIPATO, L. I Diritti Sociali nel quadro dei Diritti Fondamentali, in Giur. Cost., 2001.

RAWLS, J. Liberalismo Politico, Ed. di Comunità, Milano, 1994.

RIDOLA, P. Ridola, Diritti di Libertà e Costituzionalismo, Giappichelli, Torino, 1999.

RIDOLA, P. Introduzione in HABERLE, P. Le Libertà Fondamentali nello Stato Costituzionale, traduz. it., Nis, Roma, 1993.

RIDOLA, P., Diritti di Libertà e Mercato nella "Costituzione Europea", in A.I.C., Annuario, Cedam, Padova, 2000.

RITTER, G.A. Storia dello Stato Sociale, Laterza, Roma, Bari, 1996.

SCHMITT, C. Verfassungslehre, Berlin, 1928, traduz. it., Dottrina della Costituzione, Giuffrè, Milano, 1984.

SMEND, R. Costituzione e diritto costituzionale, traduz. it., Giuffrè, Milano, 1988.

THOMA, R. Das System der subjektiven öffentlichen Rechten und Pflichten, in ANSCHÜTZ, G., THOMA, R. Handbuch des deutschen Staatsrechts, II, Tübingen, 1932. ZAGREBELSKY, G. Diritto mite. Legge, diritto giustizia, Einaudi, Torino, 1992.

ZAGREBELSKY, G.; PORTINARO, P. P.; LUTHER, J. II Futuro della Costituzione, Enaudi, Torino, 1996. 